Jurnal Manajemen dan Kewirausahaan, Volume 8, Nomor 2, Mei 2017

ISSN: $2086-5031$

\title{
Analisis Pengaruh Promotion Mix Terhadap Keputusan Mahasiswa Kuliah Di Universitas Tamansiswa Padang
}

\author{
${ }^{1)}$ Boyke Benar, ${ }^{2)}$ Sepris Yonaldi, ${ }^{3)}$ Hafrizal Okta Ade Putra \\ ${ }^{1,2,3)}$ Fakultas Ekonomi Unitas Padang

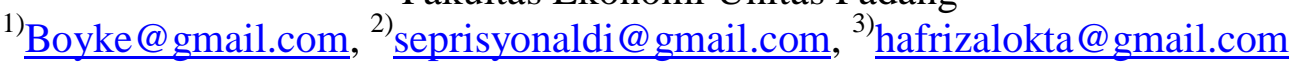

\begin{abstract}
Abstrak
Tujuan penelitian ini untuk mengetahui dan menganalisis pengaruh promotion mix terhadap keputusan mahasiswa kuliah di Universitas Tamansiswa Padang. Metode penelitian yang digunakan adalah kuantitatif deskriptif. Teknik pengambilan sampel yang digunakan adalah simple random sampling sehingga dari populasi tersebut diambil sampel sebanyak 103 responden, metode pengumpulan data yang digunakan adalah dengan menggunakan angket dan observasi dan keperpustakaan. Teknik analisa data yang digunakan adalah analisis structural equation modeling (SEM). Berdasarkan analisis structural equation modeling (SEM) pada indikator advertising, sales promotion, public relation, direct marketing, word of mounth dan event didapatkan bahwa semua indikator promotion mix berpengaruh kearah positif atau signifikan dengan nilai probability $<0,05$, sedangkan $C h i$ Square hitung $_{\text {sebesar }}$ 3086,861 > Chi_Square tabel $_{\text {S }}$ sebesar 31,671 dengan probability (p) sebesar 0,000.
\end{abstract}

Kata Kunci: Promotion Mix dan Keputusan Mahasiswa.

\section{PENDAHULUAN}

\subsection{Latar Belakang Masalah}

Promosi merupakan salah satu memutuskan kuliah di Unitas Padang. strategi yang tetap digunakan Universitas adapun kegiatan promosi yang dilakukan Tamansiswa Padang dalam meningkatkan pada tahun 2016 adalah sebagai berikut: minat calon Mahasiswa untuk

\section{Tabel 1}

Program Promosi Universitas Tamansiswa Padang

\begin{tabular}{|c|c|c|c|}
\hline No & $\begin{array}{c}\text { Jenis } \\
\text { Promosi }\end{array}$ & $\begin{array}{l}\text { Kegiatan } \\
\text { Promosi }\end{array}$ & Keterangan \\
\hline \multirow{3}{*}{1} & \multirow{3}{*}{ Advertising } & Spanduk 4x1m & $\begin{array}{l}\text { 1.30 dalam Kota Padang } \\
\text { 2.10 luar Kota Padang }\end{array}$ \\
\hline & & Billboard 6x4 m & $\begin{array}{l}\text { 1. Pesisir Selatan } \\
\text { 2. Solok } \\
\text { 3. Padang Pariaman } \\
\text { 4. Kota Padang }\end{array}$ \\
\hline & & Iklan Media & $\begin{array}{l}\text { 1. Koran Padang Ekspres 10x150 mm } \\
\text { 2. Koran Haluan 10x150 mm } \\
\text { 3. Tabloid Indonesia Raya }\end{array}$ \\
\hline
\end{tabular}


Jurnal Manajemen dan Kewirausahaan, Volume 8, Nomor 2, Mei 2017

ISSN: $2086-5031$

\begin{tabular}{|c|c|c|c|}
\hline & & & $\begin{array}{l}\text { 4.Padang TV } \\
\text { 5.Panduan perguruan tinggi di kopertis } \\
\text { wilayah } \mathrm{x} \\
\text { 6.Padang Kota metro polis } 2016 \\
\end{array}$ \\
\hline 2 & $\begin{array}{c}\text { Sales } \\
\text { Promotion }\end{array}$ & Beasiswa & $\begin{array}{l}\text { 1. Beasiswa khusus putra/i Mentawai } \\
\text { 2. Beasiswa khusus prodi pendidikan } \\
\text { matematika } \\
\text { 3. Baznas } \\
\text { 4. Bidik misi }\end{array}$ \\
\hline \multirow[t]{2}{*}{3} & \multirow[t]{2}{*}{ Public Relation } & Berita & $\begin{array}{l}\text { 1. Berita di Padang Ekspres } \\
\text { 2. Berita di Padang Haluan } \\
\text { 3. Berita di Padang TV } \\
\text { 4. Berita di TVRI Padang }\end{array}$ \\
\hline & & Media Online & Berita di WEB. Unitas-pdg.ac.id \\
\hline 4 & $\begin{array}{c}\text { Direct } \\
\text { Marketing }\end{array}$ & Surat penawaran & $\begin{array}{l}\text { 1. Surat penawaran ke SMA-SMA } \\
\text { 2. Surat penawaran ke instansi-instansi }\end{array}$ \\
\hline \multirow[t]{2}{*}{5} & \multirow[t]{2}{*}{ Word of Mount } & Komunikasi mulut ke mulut & $\begin{array}{l}\text { 1. Komunikasi mulut ke mulut melalui alumni } \\
\text { 2. Komunikasi mulut ke mulut mahasiswa } \\
\text { Universitas Tamansiswa Padang } \\
\text { 3. Komunikasi mulut ke mulut karyawan dan } \\
\text { dosen Universitas Tamansiswa Padang }\end{array}$ \\
\hline & & Aktivitas dimedia sosial & Facebook. Universitas Tamansiswa Padang \\
\hline 6 & $\begin{array}{c}\text { Event/Sponship/ } \\
\text { Kegiatan- } \\
\text { kegiatan }\end{array}$ & Program kerja & $\begin{array}{l}\text { 1. Program kerja Pemerintah Padang Pariaman } \\
\text { 2. Baznas Pemerintah Padang Pariaman }\end{array}$ \\
\hline
\end{tabular}

Sumber Data: BAK Universitas Tamansiswa Padang, 2016.

Dengan menerapkan berbagai

metode promosi tersebut sehingga

Universitas Tamansiswa Padang lebih

dikenal oleh masyarakat dan calon

mahasiswa, yang akan berdampak pada

keputusan untuk melakukan kuliah pada

Universitas Tamansiswa Padang. Dengan

terjadinya masalah tersebut peneliti

tertarik untuk melakukan sebuah

penelitian yang berjudul: Analisis

Pengaruh Promotion Mix Terhadap

Keputusan Mahasiswa Kuliah di

Universitas Tamansiswa Padang.

\subsection{Perumusan Masalah}

Berdasarkan uraian latar belakang masalah di atas, pokok permasalahan dalam penelitian ini adalah bagaimanakah pengaruh promotion mix terhadap keputusan mahasiswa kuliah di Universitas Tamansiswa Padang?

\subsection{Tujuan Penelitian}

Berdasarkan permasalahan yang telah dikemukakan, maka tujuan dari penelitian ini adalah untuk mengetahui dan menganalisis pengaruh promotion mix terhadap keputusan mahasiswa kuliah di Universitas Tamansiswa Padang? 


\section{LANDASAN TEORI, KERANGKA KONSEPTUAL DAN HIPOTESIS}

\subsection{Promotion (Promosi)}

Menurut Hurriyati (2015:57), promosi merupakan salah satu faktor penentu keberhasilan suatu program pemasaran, betapapun berkualitasnya suatu produk, bila konsumen belum pernah mendengarnya dan tidak yakin bahwa prodk tersebut akan berguna bagi mereka, maka mereka tidak akan pernah membelinya.

\subsection{Promotion Mix (Bauran Promosi)}

Menurut Kotler dan Keller (2012:479), mendefinisikan bauran promosi terdiri dari tujuh bentuk utama, yaitu, periklanan, promosi penjualan, acara dan pengalaman, hubungan masyarakat dan publis, pemasaran langsung, dan interaktif, pemasaran dari mulut ke mulut dan penjualan perseorangan. Bauran promosi terdiri dari tujuh bentuk utama, yaitu, periklanan, promosi penjualan, acara dan pengalaman, hubungan masyarakat dan publis, pemasaran langsung, dan interaktif, pemasaran dari mulut ke mulut dan penjualan perseorangan.

\subsubsection{Periklanan (advertising)}

Menurut Lupiyoadi (2013:179), periklanan merupakan salah satu bentuk dari komunikasi impersonal (impersonal commucation) yang digunakan oleh perusahaan dalam mengkonunikasikan produknya, baik barang maupun jasa. Menurut Lupiyoadi (2013:178), indikator periklanan dapat dikelompok menjadi beberapa bagian yaitu surat kabar, majalah, radio, televisi, papan reklame, surat langsung

\subsubsection{Penjualan Personal (personal} Selling)

Menurut Kotler dan Keller (2015:192), penjualan personal merupakan alat paling efektif pada tahap proses pembelian selanjutnya, terutama dalam membentuk preferensi, keyakinan, dan tindakan pembeli. Penjualan personal mempunyai 3 kualitas yang berbeda sehingga dapat dijadikan sebagai indikator dalam penelitian ini adalah interaksi pribadi, pengembangan, respons

\subsubsection{Promosi Penjualan (sales} promotion)

Menurut Hurriyati (2015:60), promosi penjualan adalah bentuk persuasi langsung melalui penggunaan berbagai insentif yang dapat diatur untuk 
merangsang pembelian produk dengan segera dan atau meningkatkan jumlah barang yang dibeli pelanggan. Tujuan dari promosi penjualan sangat beraneka ragam. Menurut Lupiyoadi (2013:180), indikator promosi penjualan adalah penawaran cuma-cuma (gratis), sampel, demo produk, kupon, pengembalian tunai, hadiah, kontes, garansi.

\subsubsection{Hubungan masyarakat (public relation)}

Menurut Schoel dalam Alma (2014:188), pubic relation is commucation boild and maintain a favorable image for a firm, maintain the goodwill of its many stokeholders, and expain its goals and purpose. Public relations adalah kegiatan komunikasi yang dimaksudkan untuk membangun image yang baik terhadap perusahaan, menjaga kepercayaan dari para pemegang saham. Menurut Lupiyoadi (2013:181), hubungan masyarakat merupakan kiat pemasaran penting lainnya, dimana perusahaan tidak hanya harus berhubungan dengan pelanggan, pemasok, dan penyalur, tetapi juga harus berhubungan dengan kumpulan kepentingan publik yang lebih besar.
Indikator hubungan masyarakat adalah publikasi, acara-acara penting, pameran, mensponsori beberapa acara.

\subsubsection{Pemasaran langsung (direct marketing)}

Menurut Kotler dan Keller (2015:240), pemasaran langsung adalah penggunaan saluran langsung konsumen untuk menjangkau dan mengirimkan barang dan jasa kepada pelanggan tanpa menggunakan perantara pemasaran. Pemasaran langsung dapat menggunakan sejumlah saluran untuk menjangkau calon pelanggan dan pelanggan perorangan. Indikator pemasaran langsung adalah surat langsung, pemasaran Katalog, telemarketing.

\subsubsection{Pemasaran Mulut ke Mulut (Word Of Mouth)}

Menurut Kotler dan Keller (2015:255), aspek kunci jaringan sosial adalah berita dari mulut ke mulut serta jumlah dan sifat percakapan dan komunikasi antara berbagai pihak. Konsumen membicarakan lusinan merek seriap hari. Meskipun banyak produk adalah produk media dan hiburan seperti film, acara TV, dan publikasi, produk makanan, jasa perjalanan, toko eceran, dan banyak jenis produk disebutkan. 
Indikator mulut ke mulut antara lain pemasaran buzz dan pemasaran viral

\subsubsection{Event (Acara)}

Menurut Kotler dan Keller (2015:225), acara kegiatan pemberian sponsor terhadap suatu acara yang merupakan bagian yang cukup pribadi dalam kehidupn konsumen dapat memperluas dan memperdalam hubungan dengan perusahaan dengan pasar sasaran. Indikator event adalah mengidentifikasi pasar sasaran atau gaya hidup tertentu, meningkatkan kesadaran perusahaan atau nama produk, menciptakan atau memperkuat persepsi tentang asosiasi citra dan merek kunci, memperkuat citra korporat, menciptakan pengalaman dan membangkitkan perasaan, mengekspresikan komitmen terhadap komunitas atau masalah sosial, menghibur klien kunci atau memberi penghargaan pada karyawan kunci, menciptakan penjualan barang dagangan atau peluang promosi.

\subsection{Keputusan Pembelian}

Menurut Kotler dan Keller (2012), keputusan pembelian konsumen adalah tahap dimana konsumen membentuk niat untuk membeli produk yang paling disukai, dimana keputusan konsumen untuk memodifikasi, menunda, atau menghindar sangat dipengaruhi resiko yang dirasakan. Menurut Kotler dan Amstrong (2012), keputusan pembelian adalah membeli merek yang paling disukai dari berbagai alternatif yang ada, tetapi dua faktor bisa berada antara niat pembelian dan keputusan pembelian. Keputusan pembelian konsumen melalui beberapa tahap terlebih dahulu yaitu pengenalan masalah, pencarian informasi, evaluasi alternatif, keputusan pembelian, perilaku pasca pembelian

\subsection{Kerangka Konseptual}

Untuk mengetahui promotion mix (advertising, sales promotion, public relation, direct marketing, word of mounth dan event) terhadap keputusan mahasiswa kuliah di universitas tamansiswa padang dapat dibentuk sebuah kerangka konseptual penelitian dapat dilihat pada gambar 2.1 berikut ini: 


\section{Gambar 1 \\ Kerangka Konseptual Penelitian}

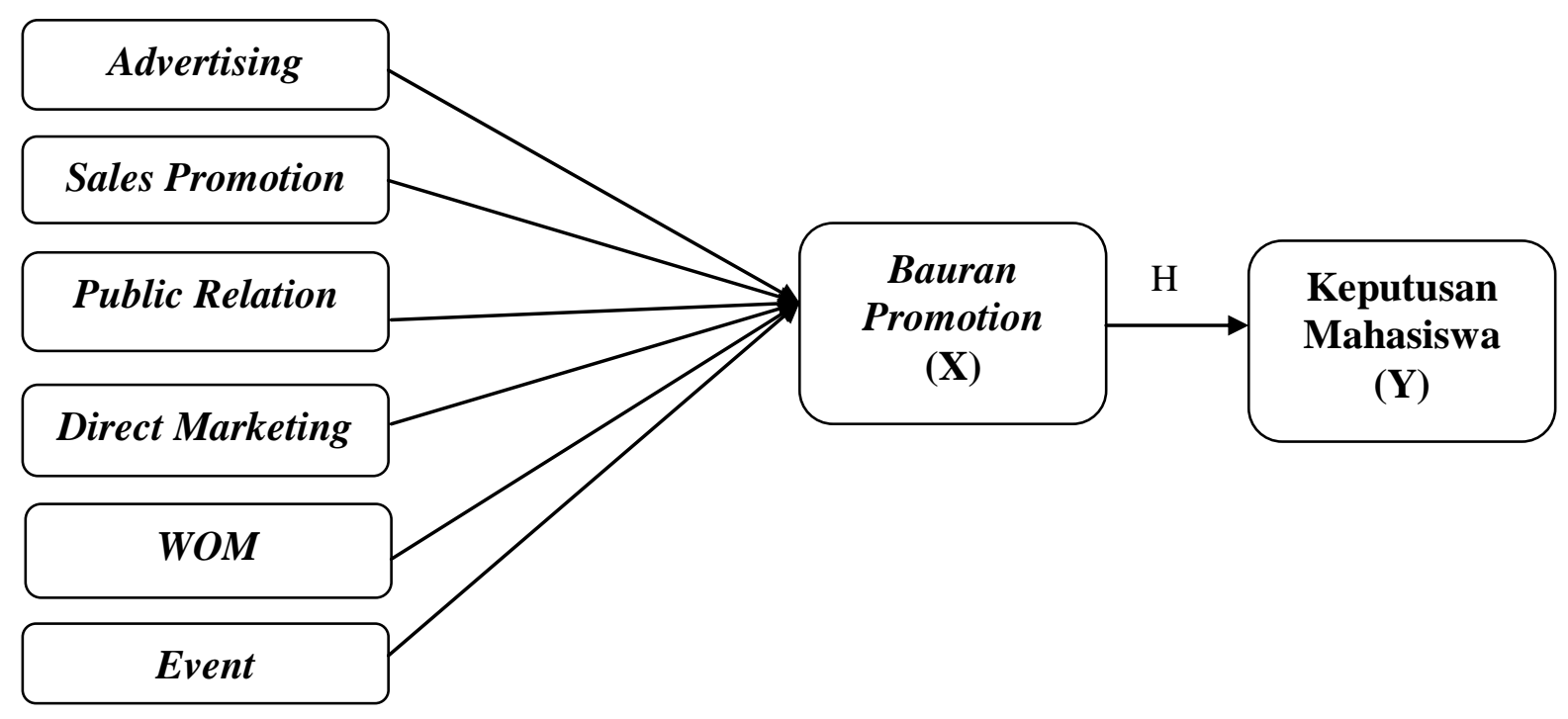

\subsection{Hipotesis Penelitian}

$\mathrm{H}$ : Diduga promotion mix berpengaruh signifikan terhadap keputusan mahasiswa kuliah di Universitas Tamansiswa Padang.

\section{METODE PENELITIAN}

\subsection{Jenis Metode Penelitian}

Penelitian ini menggunakan metode penelitian dengan pendekatan kuantitatif, yaitu metode penelitian yang berlandaskan pada filsafat positifme, digunakan untuk meneliti pada populasi atau sampel tertentu, pengumpulan data menggunakan instrumen penelitian, analisis data bersifat kuantitatif/statistik, dengan tujuan untuk menguji hipotesis yang telah ditetapkan (Sugiyono, 2013).

\subsection{Populasi dan Sampel}

Populasi dalam penelitian ini adalah Mahasiswa Universitas Tamansiswa Padang Pada Tahun 2016/2017 (ganjil) yang berjumlah sekitar 494 orang. Teknik pengambilan sampel yang digunakan dalam penelitian ini adalah Probability sampling adalah teknik pengambilan sampel yang memberikan peluang yang sama kepada setiap anggota populasi untuk menjadi sampel. Teknik yang dipakai dalam penelitian ini adalah Teknik Proportionate Stratified Random Sampling. Jumlah sampel yang diambil berdasarkan masing-masinng bagian 
tersebut ditentukan kembali dengan rumus : (Riduwan: 2007:65).

$$
\mathrm{N}=\frac{\text { Populasi Program Studi }}{\mathrm{X}}
$$

Jumlah sampel yang ditentukan

Populasi keseluruhan

Berdaarkan rumus yang

dikemukan oleh Riduwan (2007:65) tersebut maka jumlah sampel yang digunakan dalam penelitian ini berjumlah 103 orang mahasiswa Universitas Tamansiswa Padang.

\subsection{Teknik Pengumpulan Data}

Teknik pengumpulan data merupakan cara yang dipakai dalam mengumpulkan data-data yang diperoleh dalam rangka pengujian penelitian. Adapun teknik yang dipakai dalam penelitian ini adalah kuesioner (angket), observasi, dan kepustakaan.

\subsection{Teknik Analisa Data}

Teknik analisa data yang digunakan adalah analisis deskriptif, uji validitas, uji reliabilitas dan analisis structural equation modelling (SEM).

\section{HASIL PENELITIAN DAN PEMBAHASAN}

\subsection{Hasil Analisis SEM}

Menurut Bagozzi dan Fornell (1982) bahwa structural equation modelling atau model persamaan struktural yaitu generasi kedua teknik analisis multivariate yang memungkinkan peneliti untuk menguji hubungan antara variabel yang kompleks baik recursive maupun nonrecursive untuk memperoleh gambaran menyeluruh mengenai keseluruhan model. Berdasarkan analisis structural equation modeling yang telah menggunakan program AMOS 18 maka didapatkan hasil seperti Gambar 4.2 berikut ini: 
Gambar 2

Structural Equation Modelling

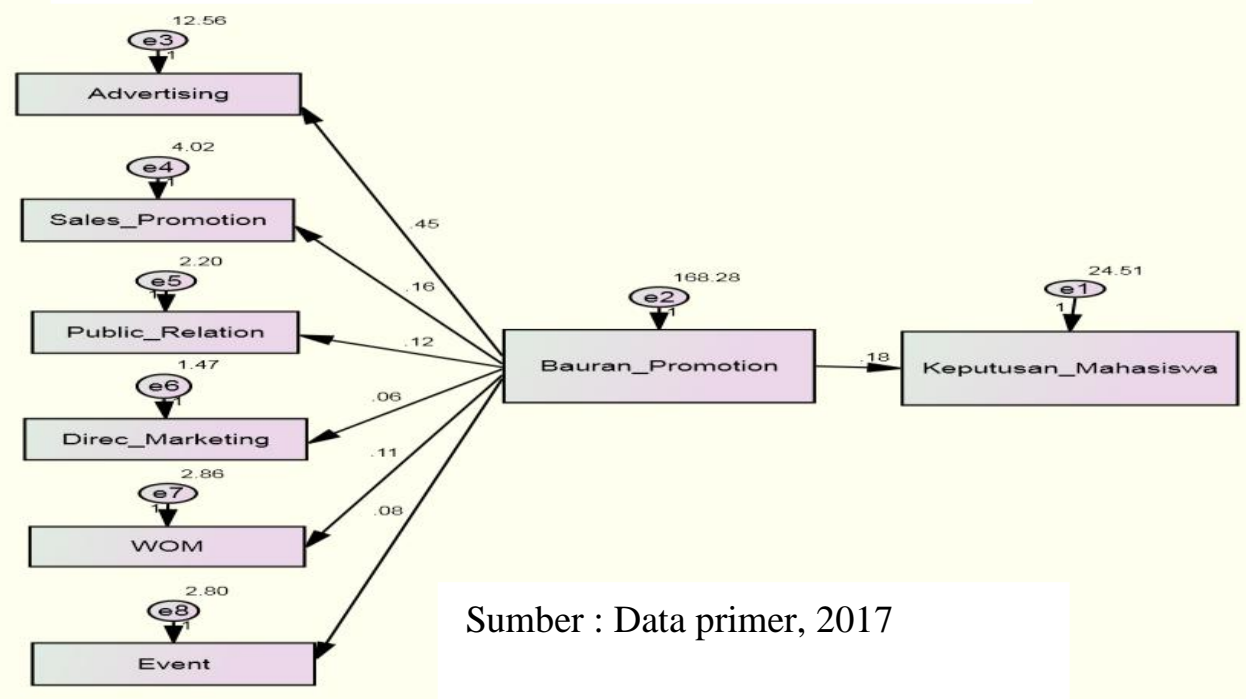

\subsubsection{Analisis Structural Equation Model}

Analisis Structural Equation Model (SEM) secara Full Model yang dimaksudkan untuk menguji model dan hipotesis yang dikembangkan dalam penelitian ini. Pengujian model dalam
Structural Equation Model dilakukan dengan dua pengujian, yaitu uji kesesuaian model dan uji signifikansi kausalitas melalui uji koefisien regresi. Hasil pengolahan data untuk analisis SEM terlihat pada Tabel 4.24 berikut ini:

\section{Tabel 2}

Hasil Regression Weights Analisis Struktural Equation Modeling

\begin{tabular}{|c|c|c|c|c|c|c|c|}
\hline & & & Estimate & S.E. & C.R. & $\mathrm{P}$ & Label \\
\hline Keputusan_Mahasiswa & $<--$ & Bauran_Promotion & .177 & .038 & 4.685 & $* * *$ & \\
\hline Direct_Marketing & $<---$ & Bauran_Promotion & .063 & .009 & 6.795 & $* * *$ & \\
\hline Public_Relation & $<---$ & Bauran_Promotion & .124 & .011 & 10.970 & $* * *$ & \\
\hline Sales_Promotion & $<---$ & Bauran_Promotion & .162 & .015 & 10.559 & *** & \\
\hline Advertising & $<---$ & Bauran_Promotion & .454 & .027 & 16.769 & $* * *$ & \\
\hline Event & $<---$ & Bauran_Promotion & .084 & .013 & 6.567 & $* * *$ & \\
\hline WOM & $<---$ & Bauran_Promotion & .114 & .013 & 8.816 & $* * *$ & \\
\hline
\end{tabular}

Sumber : Data primer, 2017

Probability $(p) * * *=0,000$ 
Berdasarkan Tabel 4.24 dapat diketahui bahwa setiap indikator pembentuk variabel laten menunjukkan hasil yang memenuhi kriteria yaitu nilai Critical Ratio (CR) > 1,96 dengan Probability (P) lebih kecil dari pada 0,05. Hasil tersebut dapat dikatakan bahwa semua indikator memberikan pengaruh secara signifikan terhadap variabel laten.

\subsection{Pembahasan Hasil Penelitian}

1. Variabel promotion mix terhadap keputusan mahasiswa

Promotion mix yang dilakukan oleh Universitas Tamansiswa Padang telah sesuai dengan yang diinginkan sehingga dapat menigkatkan keputusan mahasiswa untuk kuliah pada Universitas Tamansiswa Padang, promotion mix yang dilakukan oleh Universitas tersebut adalah periklanan, sales promotion, public relation, direct marketing, informasi mulut kemulut dan event, semua strategi yang digunakan tersebut dapat berjalan dengan baik, sehingga keputusan mahasiswa untuk kuliah pada Universitas Tamansiswa Padang lebih meningkat.

2. Variabel promotion mix terhadap indikator direct marketing
Variabel promotion mix memiliki pengaruh kearah positif atau signifikan terhadap indikator direct marketing, karena nilai Critical Ratio (CR) sebesar 6,795, dan nilai probability ( $p$ ) sebesar 0,000. Hal ini menunjukkan nilai $(\mathrm{CR})>1,96$, dan nilai probability $(p)$ $<$ 0,05, dengan demikian dapat dikatakan bahwa hipotesis I diterima. Jadi direct marketing atau pemasaran langsung yang dilakukan oleh Universitas Tamansiswa Padang dapat menarik keputusan mahasiswa untuk kuliah dengan menerapkan surat penawaran kepada intantansi pemerintahan atau swasta.

3. Variabel promotion mix terhadap indikotor public relation

$$
\text { Variabel promotion mix }
$$
memiliki pengaruh kearah positif atau signifikan terhadap indikator public relation, karena nilai Critical Ratio (CR) 10,970, dan nilai probability $(p)$ sebesar 0,000 . Hal ini menunjukkan nilai $(\mathrm{CR})>1,96$, dan nilai probability $(p)<0,05$, dengan demikian dapat dikatakan bahwa hipotesis III diterima. Jadi strategi yang digunakan Universitas 
Tamansiswa Padang telah sesuai dengan yang diinginkan, strategi yang dilakukan yaitu berbentuk public relation dengan memuat berita di Padagn Ekspres dan tayangan di TVRI padang, dengan menerapkan strategi tersebut maka keputusan mahasiswa untuk kuliah pada Universitas Tamansiswa Padang lebih meningkat.

4. Variabel promotion mix terhadap indikator sales promotion

Variabel promotion mix memiliki pengaruh kearah positif atau signifikan terhadap indikator sales promotion, karena nilai Critical Ratio (CR) sebesar 10.559, dan nilai probability $(p)$ sebesar 0,000 . Hal ini menunjukkan nilai $(\mathrm{CR})>1,96$, dan nilai probability $(p)<0,05$, dengan demikian dapat dikatakan bahwa hipotesis IV diterima. Jadi sales promotion yang digunakan oleh universitas Tamansiswa Padang dalam meningkatkan keputusan mahasiswa disebabkan dengan menerapkan strategi sales promotion yang terdiri dari pemberian beasiswa mentawai, beasiswa Baznas dan bidik misi, semua strategi yang dilakukan tersebut telah sesuai dengan yang diinginkan sehingga keputusan mahasiswa untuk kuliah pada Universitas Tamansiswa Padang lebih meningkat.

5. Variabel promotion mix terhadap indikator advertising

Variabel promotion mix memiliki pengaruh kearah positif atau signifikan terhadap indikator advertising, karena nilai Critical Ratio (CR) sebesar 16,769, dan nilai probability $(p)$ sebesar 0,000 . Hal ini menunjukkan nilai $(\mathrm{CR})>1,96$, dan nilai probability $(p)<0,05$, dengan demikian dapat dikatakan bahwa hipotesis V diterima. Jadi strategi perilklanan yang dilakukan oleh Universitas Tamansiswa telah sesuai dengan yang diharapkan, stretegi tersebut dilakukan dengan cara memasang iklan di Koran Padang Ekspres, Tabloid Indonesia Raya, Padang Kota Metro Polis dan menggunakan jasa radio sebagai alat promosi, dari berbagai jenis iklan yang digunakan oleh Universitas Tamansiswa tersebut dapat meningkatkan keputusan mahasiswa 
untuk kuliah pada Universitas Tamansiswa Padang.

6. Variabel promotion mix terhadap indikator event

Variabel promotion mix memiliki pengaruh kearah positif atau signifikan terhadap indikator event, karena nilai Critical Ratio (CR) sebesar 6,567, dan nilai Probability (P) sebesar 0,000. Hal ini menunjukkan nilai $(\mathrm{CR})>1,96$, dan nilai Probability $(\mathrm{P})<0,05$, dengan demikian dapat dikatakan bahwa hipotesis VI diterima. Jadi strategi event yang digunakan oleh Universitas Tamansiwa Padang telah sesuai dengan yang diingikan, sehingga keputusan mahasiswa untuk kuliah pada Universitas Tamansiswa Padang lebih meningkat. Peningkatan keputusan mahasiswa tersebut disebabkan karena dengan mengadakan kegiatan Bakti dan kegiatan KKN Tematik Posdaya, sehingga dapat memberikan banyak manfaat kepada masyarakat setempat.

7. Variabel promotion mix terhadap indikator informasi mulut ke mulut
Variabel promotion mix memiliki pengaruh kearah positif atau signifikan terhadap indikator informasi mulut ke mulut, karena nilai Critical Ratio (CR) sebesar 8,816 , dan nilai probability ( $p$ ) sebesar 0,000. Hal ini menunjukkan nilai $(\mathrm{CR})>1,96$, dan nilai probability $(p)<0,05$, dengan demikian dapat dikatakan bahwa hipotesis VII diterima. Jadi strategi informasi mulut ke mulut yang dilakukan oleh Universitas Tamansiswa Padang telah sesuai dengan yang diinginkan, sehingga keputusan mahasiswa untuk kuliah pada Universitas tersebut lebih meningkat, strategi yang digunakan oleh Universitas Tamansiswa tersebut seperti memanfaat rekomendasi dari keluarga dan teman-teman yang telah pernah kuliah pada Universitas Tamansiswa Padang serta menggunakan jasa media sosial, sebagai alat promosi.

\section{KESIMPULAN DAN SARAN}

\subsection{Kesimpulan}

1. Promotion mix memiliki pengaruh kearah positif atau signifikan 
terhadap direct marketing, dengan nilai Critical Ratio (CR) sebesar 6,795 , dan nilai probability $(p)$ sebesar 0,000 .

2. Promotion mix memiliki pengaruh kearah positif atau signifikan terhadap keputusan mahasiswa, dengan nilai Critical Ratio (CR) sebesar 4,685, dan nilai probability (p) sebesar 0,000.

3. Promotion mix memiliki pengaruh kearah positif atau signifikan terhadap public relation, dengan nilai Critical Ratio (CR) sebesar 10,970, dan nilai probability $(p)$ sebesar 0,000 .

4. Promotion mix memiliki pengaruh kearah positif atau signifikan terhadap sales promotion, dengan nilai Critical Ratio (CR) sebesar 10.559 , dan nilai probability $(p)$ sebesar 0,000 .

5. Promotion mix memiliki pengaruh kearah positif atau signifikan terhadap advertising, dengan nilai Critical Ratio (CR) sebesar 16,769, dan nilai probability $(p)$ sebesar 0,000 .

6. Promotion mix memiliki pengaruh kearah positif atau signifikan terhadap event, karena nilai Critical Ratio (CR) sebesar 6,567, dan nilai probability $(p)$ sebesar 0,000 .

7. Promotion mix memiliki pengaruh secara positif atau signifikan terhadap informasi mulut ke mulut, dengan nilai Critical Ratio (CR) sebesar 8,816, dan nilai probability (p) sebesar 0,000

8. Berdasarkan uji goodness of fit yang dilakukan didapatkan $\mathrm{X}^{2}$ Chi_Square $_{\text {hitung }}$ sebesar 3086,861 > Chi_Square ${ }_{\text {tabel }}$ sebesar 31,671 dengan probability ( $p)$ sebesar 0,000 , hal ini menunjukkan tidak terjadinya perbedaan antara model yang diprediksi dengan data pengamatan.

\subsection{Saran}

1. Variabel Advetising

Diharapkan pihak manajemen Universitas Tamansiswa Padang terus meningkatkan pemasangan spanduk agar memberikan informasi yang jelas kepada calon mahasiswa baru, sehingga calon mahasiswa dapat datang secara langsung ke Universitas Tamansiswa Padang.

2. Variabel Sales Promotion 
Jurnal Manajemen dan Kewirausahaan, Volume 8, Nomor 2, Mei 2017

ISSN: $2086-5031$

Diharapkan pihak manajemen Universitas Tamansiswa Padang menambah kuota penerima beasiswa supaya calon mahasiswa baru tergiur dengan beasiswa yang diberikan, sehingga dapat merekomendasikan kepada orang lain untuk kuliah pada Universitas Tamansiswa Padang.

3. Variabel Public Relation

Diharapkan pihak manajemen Universitas Tamansiswa Padang memuat berita di Padang Ekspres secara terus menerus, agar calon mahasiswa baru mendapatkan informasi yang jelas ketika membutuhkan tempat kuliah yang baik.

\section{Variabel Direct Marketing}

Diharapkan pihak manajemen Universitas Tamansiswa Padang mempertahankan surat penawaran yang telah dilakukan kepada instansi pemerintahan dan juga swasta, agar Universitas Tamansiswa Padang lebih dikenal oleh banyak orang baik di Kota Padang maupun di luar Kota Padang.
5. Variabel Informasi Mulut ke Mulut Diharapkan pihak manajemen Universitas Tamansiswa Padang memberikan kesan yang baik kepada mahasiswa ataupun kepada alumni, supaya dapat merekomendasikan kepada temanteman dan keluarga yang sedang membutuhkan tempat kuliah.

6. Variabel Event

Diharapkan pihak manajemen Universitas Tamansiswa Padang mempertahankan Kemah Bakti Mahasiswa $\quad(\mathrm{KBM}) \quad$ yang dilaksanakan supaya terjalin hubungan yang baik masyarakat, sehingga ketika anak, ataupun keluarga yang membutuhkan tempat kuliah dapat merekomendasikan Universitas Tamansiswa Padang.

\section{DAFTAR PUSTAKA}

Alma, Buchari. 2013. Manajemen Pemasaran dan Pemasaran Jasa. Bandung: Edisi Revisi. Penerbit Alfabeta.

Ghozali, I. dan Fuad. 2005. Structural Equation Modelling (Teori, Konsep, dan Aplikasi Menggunakan AMOS versi 16. Semarang: Badan Penerbit UNDIP. 
Ghozali, Imam. 2006. Aplikasi Analisis Multivariate Dengan Program SPSS. Cetakan Keempat. Semarang: Badan Penerbit Universitas Diponegoro.

Hurriyati, Ratih. 2015. Bauran Pemasaran dan Loyalitas Konsumen. Bandung: CV. Alfabeta.

Kotler, Philip dan Kelvin L. Keller. 2012. Marketing Manajemen. Jersey : Person Education, inc.

Kotler, Philip dan Amstrong. Gery. 2012. Prinsip-prinsip Pemasaran. Jakarta: Edisi 13. Jilid 2. Penerbit Erlangga.

Kotler, Philip dan Kelvin L. Keller. 2015. Manajemen Pemasaran. Jakarta: Edisi 13. Jilid 2. Penerbit: Erlangga.

Lupiyoadi, Rambat. 2013. Manajemen Pemasaran Jasa Berbasis Kompetensi. Edisi 3. Jakarta: Salemba Empat.

Riduwan. 2007. Sampel Penelitian . Edisi Kedua. Yogyakarta. Penerbit Hendry.

Ruslan, Rosady. 2010. Metode Penelian Public Reation dan Kominikasi. Jakarta: Raja Garafindo Persada.

Sofyan dan Heri Kurniawan. 2009. SPSS Complete. Cetakan pertama. Jakarta: PT. Salemba Infotek.
Sugiyono. 2012. Metode Penelitian Bisnis. Cetakan ke 16, Bandung: Penerbit Alfabeta.

Sugiyono. 2013. Metode Penelitian Manajemen. Bandung: Penerbit Alfabeta.

Suntoyo, Danang. 2013. Perilaku Konsumen (Panduan Riset Sederhana untuk Menggali Konsumen). Yogyakarta: CAPS. 